\title{
Landscape of displacement and place
}

Review by Sarah J. Martin *

Memorial University of Newfoundland

Review of Real Pigs: Shifting V alues in the Field of Local Pork, by Brad Weiss. (2016). Published by Duke University Press.

Available as hardcover, paperback, and ebook; 312 pages.

Publisher's website: https://www.dukeupress.edu/real-pigs

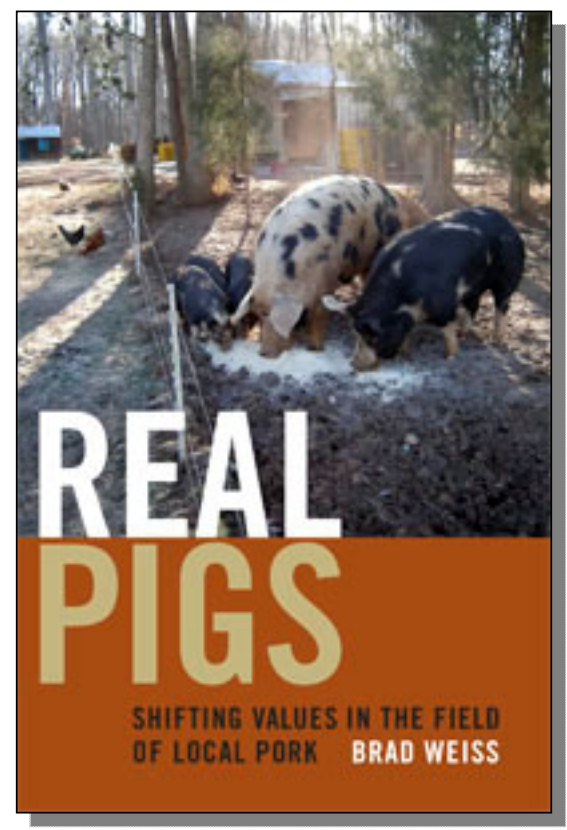

Submitted November 21, 2016 / Published online March 8, 2017

Citation: Martin, S. J. (2017). Landscape of displacement and place [Book review].

Journal of Agriculture, Food Systems, and Community Development, 7(2), 157-159.

http://dx.doi.org/10.5304/jafscd.2017.072.008

Copyright (C 2017 by New Leaf Associates, Inc.

A s I wasting Values in the Field of Local Pork, Hurricane Matthew was wreaking havoc on the U.S. East coast, and North Carolina's industrial pig farm lagoons of waste were overflowing (New York Times Editorial Board, 2016). The storm brought the horrific environmental effects of North Carolina's confined animal feeding

* Sarah J. Martin, Assistant Professor, Department of Political Science; Science Building 2046; Memorial University of Newfoundland; St. John's, NL A1B 3X9 Canada.

Sarah Martin specializes in the global political economy of food and agriculture, and is currently co-editing a book on sustainable meat consumption. She can be contacted at sarahmartin@mun.ca. operations (CAFOs) into view once again. Once again, because the lagoons were breached in 1996 and again in 1999, when Hurricane Floyd and Hurricane Fran set down. Around the same time, journalists were uncovering the unsavory political and legislative changes that fostered North Carolina's CAFO model of pork production, including the growth of contracting and excessive corporate control. While this story will be familiar to many readers, Weiss has written a fascinating account of how a niche market has developed, centered on pastured local pork in reaction to this CAFO "landscape of displacement."

Real Pigs is an ethnography of the values of consumption of the local pork market in the Piedmont Region of North Carolina. It is an 
exploration of how communities, or publics, gather and create values such as authenticity and discernment centered on the Ossabaw Island hog. In contrast to the industrial hog production landscape that "undermines the kind of depth of connoisseurship required for the appreciation of terroir [taste of place]" (p. 8), Weiss traces the practices that underpin and sustain webs of qualifications and build "an economy of quality" (p. 8). He describes an "ethos-driven cuisine" that drives the people who raise, fabricate (that is, break down an animal carcass), and market pork, as well as those who consume it. For example, the farmers market is described as a niche within the capitalist relations where values are set, in concert with other sites such as the farm and restaurants. Raising animals for meat requires not only farms, and farmers to breed, care for, and feed the animals, but also the work of transforming the animals into something consumable. This requires many interventions, and many hands to do the labor. From butchering, to markets, and then to the table, taste is mediated as animals are raised, killed, fabricated into edible portions, prepared, and consumed. Throughout the book, Weiss asks us to reflect on the values and qualities that make up human-animal relations as animals become meat. The values of farm to fork, and snout to tail, are concrete, and produced through these values, according to Weiss.

Weiss provides a compelling and fascinating account of the rise of industrial hog farming in North Carolina. The structure of industrial hog farming limited alternative relationships for animal raising, distribution, and marketing. A few large corporations benefitted from the state's targeted tax breaks and subsidies, and in turn leveraged the legislative and political support to limit marketing opportunities outside the corporation's ambit, leaving few opportunities for independent farmers to access processing facilities and markets. It is within these limited spaces that pastured pork arose.

This book is the story of how those outside that system developed a small but vital pasturedpig niche-market with an array of support. A pilot program was developed initially in 2002 to supply the national natural meat wholesaler Niman Ranch as they attempted to expand. While the project failed, it left a minimal infrastructure of pastured pork production that was supported by agricultural extension expertise from state colleges, grants from the Golden LEAF Foundation, ${ }^{1}$ and a community of local farmers. Both public and private support fostered the connections for production, yet the demise of the Niman Ranch project broke the connection to a market for the pork. The result was that a group of farmers, artisans, and other nonstate actors developed direct marketing and with it a new set of connections to consumers.

There are some wonderful stories in the book such as the Ossabaw Island Hog and its progenitors, which are the key "agricultural icon of the Piedmont and the movement to promote local foods" (p. 61), highly valued for its flavor. This breed is unusual because it was isolated for centuries after the Spanish introduced it to Ossabaw Island off the coast of Georgia; it is related to the hogs that are used for Jamón ibérico, a highly valued artisanal charcuterie product in Spain. The result is that this niche market on the one hand developed locally, but on the other also drew on cosmopolitan values and tastes. Weiss describes how "real pigs" were made through a chain of qualities (such as connoisseurship) and practices (such as butchery). As a former meat cutter, I was especially interested in the chapter "Pigs in Parts," where Weiss describes how connections are built between the pigs and a discerning public through performative butchery workshops. The workshop participants interact with the pig's carcass, experiencing "fleshly discomfort" with an "incomplete pig" (p. 163). Weiss weaves a fascinating tale of connections and disconnections that produce locality, taste, and discernment.

The strength of the book is the political economy analysis of the industrialization of livestock, and how a niche market was at once a product of it and also a reaction to it. A few areas that would benefit from further work include the concept of connections and the role of the state and governance. With regard to connections, even though industrial hog production is unjust, violent,

\footnotetext{
1 The Golden LEAF Foundation is funded through the settlement agreement between North Carolina (and 45 other states) with tobacco companies.
} 
and environmentally destructive, it is still made up of connections. What is the practice of discernment when purchasing pork from a supermarket? Who eats the industrial landscape-and is there such a thing as an industrial terroir? The second area would be a closer examination of issues of class and race. We know that the industrial diet and environmental degradation have uneven effects across class and racialized communities. Although Weiss does address some of these issues, further research in this area would be welcomed.

The second area that would benefit from further research is the roles of the state and of nonstate actors' rules and regulations. The state is mostly sidelined in Weiss's account, except for an important discussion of expertise and agricultural extension. The governance of this niche market is shaped partly by the rules of farmers markets and partly by the involvement of nonprofits and other nonstate actors. So unlike the corporate-state bargain that facilitated the growth of the industrial model, this niche market relies on market connections, and almost exclusively on voluntary principles. Weiss passingly mentions the precarious position of farms and supporters of local pork, such as chefs who lose money when utilizing local pork items. The state has long been involved in supporting agriculture; will these self-governing, voluntary efforts be sustainable?

Real Pigs will be of interest to practitioners who are developing new markets, with its biographical stories of the people who are building the connections and its portrait of how taste is constructed in place. Making pigs local, according to Weiss, involves animal husbandry, marketing strategies, and social networking. Yet he is sensitive to the cosmopolitan values that inform "locality." The book will be of interest also to those who are exploring how markets are built and sustained over time, and how complex relationships support often precarious niche markets and foodways.

\section{Reference}

New York Times Editorial Board. (2016, October 25). North Carolina's noxious pig farms [Editorial]. New York Times. Retrieved from https://www.nytimes. com/2016/10/25/opinion/north-carolinasnoxious-pig-farms.html 